\title{
LABORATORY STUDIES OF THE OPTICAL PROPERTIES OF YOUNG SEA ICE*
}

\author{
By Donald K. Perovich and Thomas C. Grenfell \\ (Department of Atmospheric Sciences, University of Washington, Seattle, Washington 98195, \\ U.S.A.)
}

\begin{abstract}
Laboratory experiments were performed to determine the optical properties of young salt ice and to examine correlations between the optical properties and the state of the ice. Ice was grown at different temperatures $\left(-10,-20,-30\right.$, and $\left.-37^{\circ} \mathrm{C}\right)$ from water of different salinities $\left(0,16\right.$, and $\left.31 \%{ }^{\circ}\right)$. The experiments were conducted in a cylindrical tank $\mathrm{I} \mathrm{m}$ in diameter designed to approximate natural ice growth and to permit in situ optical measurements. Observed incident, reflected, and transmitted irradiances were used in conjunction with a modified Dunkle and Bevans photometric model to determine spectral albedos and extinction coefficients. Cold ice only $0.25 \mathrm{~m}$ thick had albedos which were comparable to the values for 2 to $3 \mathrm{~m}$ multi-year ice examined by previous researchers during the summer melt season; extinction coefficients were 1.5 to 15 times greater. As the ice temperature and hence brine volume decreased, both albedo and extinction coefficient increased; when the ice temperature dropped below the eutectic point, they increased sharply. In addition, ice grown at lower air temperatures had greater albedos and extinction coefficients even when ice temperatures were the same. Variations in the optical properties of the ice are determined by changes in the amount of brine and its distribution; thus the optical properties of salt ice depend not only on ice temperature but on initial growth rate. Variations in ice salinity over the range $4 \%$ to $14 \%$ produced no detectable changes in the optical properties.
\end{abstract}

RÉsumÉ. Études en laboratoire des propriétés optiques de la jeune glace salée. On a pour suivi des expériences en laboratoire pour déterminer les propriétés optiques de la jeune glace salée et examiner les corrélations entre les propriétés optiques et l'état de la glace. Les glaces étaient fabriquées à des températures différentes $\left(-10,-20,-30\right.$, et $\left.-37^{\circ} \mathrm{C}\right)$ à partir d'eau de salinités différentes $(0,16$, et $31 \%)$. Les expériences ont été conduites dans une enceinte cylindrique de $1 \mathrm{~m}$ de diamètre dessinée pour se rapprocher des conditions naturelles de croissance de la glace et pour permettre in situ des mesures optiques. On a utilisé les rayonnements incidents réfléchis et transmis ainsi qu'un modèle photométrique modifié de Dunkle et Bevans pour déterminer les albédos spectraux et les coefficients d'extinction. De la glace froide sous seulement $0,25 \mathrm{~m}$ d'épaisseur, à des albédos comparables aux valeurs trouvées par d'autres chercheurs examinant pendant la saison de fusion estivale des glaces pluriannuelles de 2 à $3 \mathrm{~m}$ d'épaissuer; les coefficients d'extinction étaient de 1,5 à 15 fois plus grands. Lorsque la température de la glace et par conséquent la teneur en saumure diminuait, l'albédo et le coefficient d'extinction s'accroissait; si la température tombe en-dessous du point eutectique ils àugmentaient brusquement. De plus, les glaces formées aux plus basses températures de l'air ont des albédos et des coefficients d'extinction plus forts, même lorsque les températures de la glace sont les mêmes. Les variations dans les propriétés optiques de la glace sont déterminées par les changements dans la teneur en saumure et dans sa distribution; par conséquent, les propriétés optiques de la glace salée dépendent non seulement de la température de la glace mais de son mode de croissance initiale. Des variations dans la salinité de la glace de $4 \%$ à $14 \%$ n'ont pas produit de changement décelables des propriétés optiques.

ZuSAMmENFASSUNG. Laboruntersuchungen der optischen Eigenschaften jungen, salzhaltigen Eises. Zur Bestimmung der optischen Eigenschaften jungen, salzhaltigen Eises und zum Studium der Zusammenhänge zwischen den optischen Eigenschaften und dem Zustand des Eises wurden Laborversuche angestellt. Eis wurde bei verschiedenen Temperaturen $\left(-10,-20,-30\right.$, und $\left.-37^{\circ} \mathrm{C}\right)$ aus Wasser mit verschiedenem Salzgehalt $(0,16$, und $31 \%$ ) erzeugt. Die Versuche fanden in einem zylindrischen Tank von $\mathrm{I} \mathrm{m}$ Durchmesser statt, da zur annähernd natürlichen Erzeugung von Eis und zur optischen in sit-Messung eingerichtet war. Zur Bestimmung der spektralen Albedo und des Extinktions-Koeffizienten aus einem modifizierten photometrischen Modell nach Dunkle und Bevans wurden die Beobachtungen einfallender, reflektierter und durchfallender Beleuchtungswerte herangezogen. Kaltes Eis von nur $0,25 \mathrm{~m}$ Dicke wies Albedowerte auf, die mit denen für 2 bis $3 \mathrm{~m}$ dickes, mehrjähriges Eis vergleichbar waren, das von früheren Forschern während der sommerlichen Schmelzperiode untersucht worden war; die Extinktionskoeffizienten lagen I,5 bis I5-mal höher. Nimmt die Eistemperatur und damit das Solevolumen ab, so wachsen Albedo und Extinktionskoeffizient; sank die Eistemperatur unter den eutektischen Punkt, so nahmen beide sprunghaft zu. Ausserdem hatte Eis, das bei niedrigen Lufttemperaturen entstanden war, grössere Albedowerte und Extinktionskoeffizienten, auch wenn die Eistemperatur dieselbe war. Änderungen in den optischen Eigenschaften des Eises ergeben sich aus Anderungen des Solegehaltes und ihrer Verteilung; somit hängen die optischen Eigenschaften von salzhaltigem Eis nicht nur von der Eistemperatur sondern auch von der ursprünglichen Wachstumsrate ab. Änderungen im Salzgehalt über den Bereich von 4 bis $14 \%$ bewirkten keine erkennbaren Änderungen der optischen Eigenschaften.

* Contribution 573, Department of Atmospheric Sciences, University of Washington. 


\section{INTRODUCTION}

The overall energy balance of the polar regions is greatly influenced by the reflection, absorption, and tránsmission of short-wave radiation by sea ice. Radiation absorbed in the ice or upper ocean retards freezing and contributes to melting thus affecting the equilibrium thickness of the ice. The amount and spectral distribution of light penetrating into and under the ice is also important biologically in determining primary productivity.

The ice cover of the Arctic Ocean is both vertically and horizontally complex. Vertically, the ice exhibits variations in crystal structure, brine volume, temperature, and bubble density. Horizontally, thickness can vary from open water to thick pressure ice over distances of only a few tens of meters; surface conditions are diverse including melt ponds, bare ice, and snowcovered ice. Unlike its constituent parts of brine and fresh ice, sea ice is dominated optically by scattering rather than absorption. The intricate and highly variable structure of sea ice, consisting of air bubbles, ice platelets, and brine pockets and channels, considerably complicates the processes of radiative transfer within the medium.

Due to the importance of net short-wave radiation in heat-budget calculations, measurements of albedos have long been a routine part of data collection in the Arctic. Typical values of wavelength-integrated albedo are 0.06-0.1 for open water (Burt, 1954), 0.2-0.6 for melt ponds (Hanson, I961; Langleben, I971), 0.5-0.7 for melting bare ice (Chernigovskiy, 1963), to as much as 0.9 for freshly fallen snow (Timerev, 1970). Areally averaged albedos measured from high towers and aircraft (Langleben, I968; Hanson, 196r) have been used to formulate empirical relations between albedo, the degree of puddling, and the amount of open water. Spectral albedos have been determined by Grenfell and Maykut (I977) from 400 to I ooo $\mathrm{nm}$ for an extensive range of Arctic ice and snow conditions. Their results show that the albedo curves are quite sensitive to the amount of liquid water in the surface layer. A reduction of albedo, much more pronounced at longer wavelengths, occurs when surface water accumulates.

Measurements of radiation extinction in thick first-year and multiyear ice also have been reported. From changes in ice temperature profiles Untersteiner (196i) calculated an optical bulk extinction coefficient $\kappa$ of $1.5 \mathrm{~m}^{-1}$ for multiyear sea ice. Using photoelectric cells Thomas (1963) measured $\kappa$ values of $\mathrm{r} .1 \mathrm{~m}^{-1}$ for pack ice and $2.2 \mathrm{~m}^{-1}$ for shore-fast ice. Weller and Schwerdtfeger (1967), studying I.35 $\mathrm{m}$ thick Antarctic sea ice, determined values of bulk extinction coefficient of $1.2 \mathrm{~m}^{-1}$ using a thermopile radiometer and $\mathrm{r} .0 \mathrm{~m}^{-1}$ from temperature profiles. Spectral measurements of light penetration through first-year (Maykut and Grenfell, 1975) and multiyear (Grenfell and Maykut, 1977) sea ice were taken with a submersible spectrophotometer. The wide range of ice types investigated showed that extinction coefficients are lowest for ice beneath an old melt pond, increasing in order for first-year blue ice, the interior of multiyear white ice, and the surface granular layer of multiyear white ice. In all cases the spectral extinction coefficient was fairly constant from 400 to $500 \mathrm{~nm}$, exhibiting a gradual rise between 500 and $600 \mathrm{~nm}$, then a dramatic increase beyond $600 \mathrm{~nm}$.

Some research has been done in attempting to correlate the optical properties with the physical state of sea ice. Weller (1972), studying young growing sea ice, observed an increase of bulk albedo with thickness. Laboratory experiments conducted by Davis and Munis (1973) indicated that the extinction coefficient increased as the ice salinity increased. Further investigations of the relationship between salinity and extinction coefficient (Lane, 1975) showed a decrease in transmission as salinity increased, though this dependence was very weak for salinities greater than $5 \%$. However, the influence of ice temperature, growth rate, and bubble density on the optical properties of sea ice is not well known.

Most of the research on the optical properties of sea ice has been concerned with thick ice. Due to the hazards involved, the optical properties of thin young sea ice have not been studied in the field. Recent calculations (Maykut, I978; Grenfell, 1979) show that although thin ice 
accounts for only a small percentage of the ice cover, it transmits large amounts of energy to the ocean and can strongly influence the regional heat budget.

The most practical way to study the optical properties of young ice is through laboratory experiments which allow environmental control and avoid the inherent hazards of the field. This paper describes the results of such a laboratory program investigating the optical properties as a function of wavelength from 400 to I 000 nanometers (Perovich, I 979). The dependence of the optical properties on such physical parameters as growth rate, air temperature, salinity, and brine volume was examined, and a photographic analysis was made to relate variations in the optical properties to changes in the ice structure.

\section{LABORATORY EXPERIMENTS}

Eight experiments were conducted for ice grown from $\mathrm{NaCl}$ solutions of different salinities over a range of air temperatures. Three categories were defined on the basis of water salinity: fresh water, salinity comparable to Arctic ocean water $(31 \%)$, and water of intermediate salinity $(16 \%)$. Ice was grown at an air temperature of $-15^{\circ} \mathrm{C}$ for the two fresh-ice experiments; $-\mathrm{IO},-20,-30$, and $-37^{\circ} \mathrm{C}$ for the full salinity experiments; and $-\mathrm{IO}$ and $-20^{\circ} \mathrm{C}$ for the intermediate salinity cases. The optical properties of salt ice are assumed to be the same as those of sea ice.

The ice was grown in a cylindrical "Plexiglas" (polymethyl methacrylate) tank o.6 I m high and $0.95 \mathrm{~m}$ in diameter (Fig. I). A cylindrical design was chosen to avoid stress concentrations, enabling the use of a very thin "Plexiglas" wall $(3.75 \mathrm{~mm})$ while maintaining structural integrity. Mirrored "Plexiglas" was selected to minimize optical edge effects by making the ice sheet appear larger in areal extent. The tank's base was $12.5 \mathrm{~mm}$ thick "Plexiglas" painted black to minimize reflection. Both the bottom and the walls of the tank were thermally insulated to insure the growth of a flat ice sheet.

The source of illumination was a "sun" consisting of nine, $500 \mathrm{~W}$ incandescent light bulbs. Blue-frosted "superfloods" with a color temperature of $4800 \mathrm{~K}$ were used since they provided a larger proportion of short wavelength light than conventional incandescent bulbs. To produce uniform illumination the lights were mounted on a glossy white circular piece of

\section{ILLUMINATION}

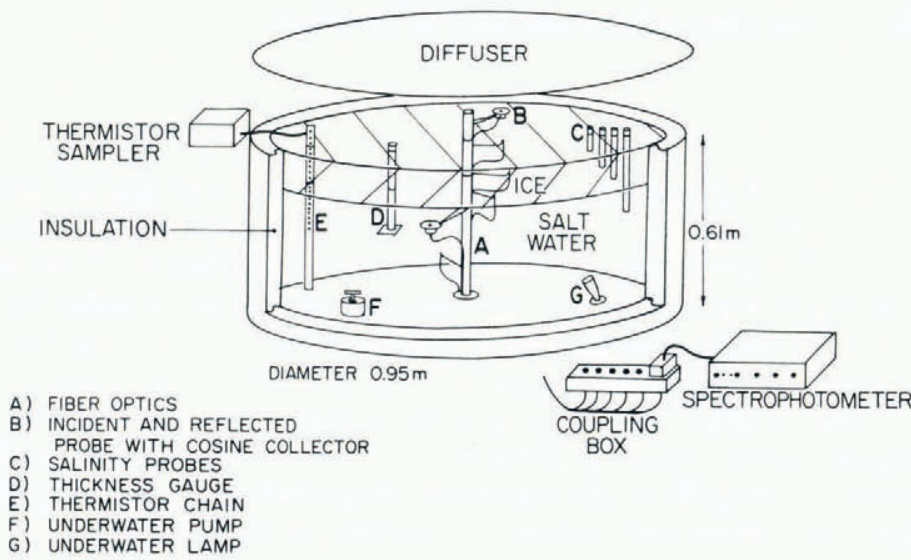

Fig. I. The tank system. The walls are mirrored "Plexiglas" and the bottom is painted flat black. 
wood, one meter in diameter, in an array consisting of a hexagon with an inner triangle. A sheet of opal "Plexiglas" was placed between the "sun" and the ice surface to produce diffuse lighting conditions similar to cloudy skies. A fan enhanced growth by providing air circulation and an underwater pump was used to circulate the water retarding excess growth of ice down the wall of the tank.

Incident, reflected, and transmitted spectral irradiances over the wavelength region 400 to $\mathrm{I}$ ooo $\mathrm{nm}$ were measured with the profiling spectrophotometer described by Roulet and others (r974). The key feature of this spectrophotometer was the use of fiber optics to transmit light from the interior of the medium to the instrument, allowing in situ optical measurements to be made. The glass fiber-optics probes were mounted on a central "Plexiglas" column in a spiral array as shown in Figure I. Typically six probes were used; an above-surface probe for measurements of incident and reflected irradiances, four probes frozen into the ice at depths of $0.03,0.06$, 0.10, and $0.19 \mathrm{~m}$, and a sixth probe always below the ice at a depth of $0.33 \mathrm{~m}$ measuring transmitted irradiances. A specially designed coupling box made it possible to connect the spectrophotometer to the six different fiber-optics probes. The optical data were recorded on magnetic tape for subsequent computer processing.

Ice thickness was measured with a thickness gauge consisting of a $0.5 \mathrm{~m}$ long section of plastic pipe, graduated in intervals of $2.5 \mathrm{~mm}$, with a flat "Plexiglas" base. The tube was frozen vertically into the ice and measurements were made by pulling the gauge upwards until the base reached the bottom of the ice. A chain of thermistors was used to obtain vertical temperature profiles. Temperatures were usually recorded at $30 \mathrm{~mm}$ above the surface, at the surface, and at $20 \mathrm{~mm}$ intervals within the ice. The thermistors were potted in "Silastic" on a "Plexiglas" strip and painted with marine varnish to provide electrical insulation. To determine salinity profiles several lengths of plastic pipe, I I $\mathrm{mm}$ in diameter, were frozen into the ice. When a salinity profile was needed, a tube was removed from the ice, providing an ice core which was then cut into sections $20 \mathrm{~mm}$ long. After the sections melted, the salinity was measured using an ENDECO Type 102 optical salinometer.

Each experiment consisted of two parts. The first was a growth phase where the air temperature of the cold room was held constant and the second was a warming phase where the air temperature was raised to $0^{\circ} \mathrm{C}$ in two or three increments and the ice allowed to attain a linear temperature profile at each new air temperature.

At the end of the growth phase a core was removed for photographic analysis of the ice structure, and vertical and horizontal slabs $20 \mathrm{~mm}$ in thickness were prepared. Photographs were taken in natural light to display prominent brine channels and vapor bubbles. The slabs were then thinned to between $\mathrm{I}$ and $3 \mathrm{~mm}$ and photographed in transmitted light between crossed polaroids to show the platelet and crystal structure.

\section{THEORY}

A modified Dunkle and Bevans (1956) photometric model was used to calculate extinction coefficients from measurements of incident, reflected, and transmitted irradiances. The theory assumes an isotropically scattering, optically homogeneous medium, finite in depth, infinite in width and breadth, with a diffuse radiation field at all depths. Unlike the commonly-used Bouguer-Lambert law, which assumes a semi-infinite medium, the Dunkle and Bevans model can represent a thin slab. The formulation used is similar to that of Grenfell and Maykut ( 1977 ) with the added complications of specular reflection at the upper surface and transmitted measurements made within, as well as beneath the ice. The Dunkle and Bevans model assumes two streams, an upwelling and a downwelling irradiance, entailing the solution of the following simultaneous differential equations (Dunkle and Bevans, 1956):

$$
\mathrm{d} F_{\downarrow}(z, \lambda)=-k_{\lambda} F_{\downarrow}(z, \lambda) \mathrm{d} z-r_{\lambda} F_{\downarrow}(z, \lambda) \mathrm{d} z+r_{\lambda} F_{\uparrow}(z, \lambda) \mathrm{d} z
$$


and

$$
\mathrm{d} F_{\uparrow}(z, \lambda)=k_{\lambda} F_{\uparrow}(z, \lambda) \mathrm{d} z-r_{\lambda} F_{\downarrow}(z, \lambda) \mathrm{d} z+r_{\lambda} F_{\uparrow}(z, \lambda) \mathrm{d} z
$$

where $F_{\downarrow}(z, \lambda)$ is the downwelling spectral irradiance, $F_{\uparrow}(z, \lambda)$ is the upwelling spectral irradiance, $k_{\lambda}$ is the spectral absorption coefficient, $r_{\lambda}$ is the spectral volume reflectance coefficient, and $z$ (increasing downward) is the depth within the ice. The boundary conditions for this problem are

$$
z=0: \quad F_{\downarrow}(0, \lambda)=\left(\mathrm{I}-R_{0}\right) F_{0}+R_{0} F_{\uparrow}(0, \lambda)
$$

and

$$
z=H: \quad F_{\uparrow}(H, \lambda)=0
$$

where $R_{0}$ is the specular reflectivity of the upper surface, $F_{0}(\lambda)$ is the incident irradiance at a given wavelength, and $H$ is the thickness of the ice.

For a homogeneous, plane parallel slab of thickness $H$, with the above boundary conditions, the solutions to Equations (I) and (2) are

and

$$
F_{\downarrow}(z, \lambda)=\frac{\left(\mathrm{I}-R_{0}\right) F_{0}(\lambda) \sinh \left[\kappa_{\lambda}(H-z)+\gamma\right]}{\sinh \left[\kappa_{\lambda} H+\gamma\right]-R_{0} \sinh \left[\kappa_{\lambda} H\right]}
$$

$$
F_{\uparrow}(z, \lambda)=\frac{\left(\mathrm{I}-R_{0}\right) F_{0}(\lambda) \sinh \left[\kappa_{\lambda}(H-z)\right]}{\sinh \left[\kappa_{\lambda} H+\gamma\right]-R_{0} \sinh \left[\kappa_{\lambda} H\right]}
$$

where $\kappa_{\lambda}=\left(2 k_{\lambda} r_{\lambda}+k_{\lambda}^{2}\right)^{\frac{1}{2}}$ is the extinction coefficient and $\gamma=\operatorname{arsinh}\left(\kappa_{\lambda} / r_{\lambda}\right)$. Combining Equations (5) and (6) relationships are written in terms of the measured values of albedo and transmittance. The albedo $\alpha(\lambda)$ is given by

$$
\alpha(\lambda)=\frac{R_{0} F_{0}(\lambda)+\left(\mathrm{I}-R_{0}\right) F_{\uparrow}(\mathrm{o}, \lambda)}{F_{0}(\lambda)}=R_{0}+\frac{\left(\mathrm{I}-R_{\mathrm{o}}\right)^{2} \sinh \left(\kappa_{\lambda} H\right)}{\sinh \left(\kappa_{\lambda} H+\gamma\right)-R_{0} \sinh \left(\kappa_{\lambda} H\right)} .
$$

The transmittance $T(z, \lambda)$ is expressed as

$$
T(z, \lambda)=\frac{F_{\downarrow}(z, \lambda)}{F_{0}(\lambda)}=\frac{\left(\mathrm{I}-R_{0}\right) \sinh \left[\kappa_{\lambda}(H-z)+\gamma\right]}{\sinh \left(\kappa_{\lambda} H+\gamma\right)-R_{0} \sinh \left(\kappa_{\lambda} H\right)} .
$$

Equations (7) and (8) cannot be explicitly solved for $\kappa_{\lambda}$ and $r_{\lambda}$. Instead they were determined by numerically inverting the equations using a two-dimensional Newton-Raphson iteration scheme. Convergence was rapid, usually occurring within three iterations.

To aid in the analysis of interrelationships between optical properties and other ice parameters, bulk albedos were calculated from

$$
\alpha_{\mathrm{BC}}=\frac{\int_{\int_{0}}^{\mathrm{I} \alpha_{\lambda} F_{0}} F_{0}(\lambda) \mathrm{d} \lambda}{\int_{400}^{1000} F_{0}(\lambda) \mathrm{d} \lambda}
$$

using relative values of $F_{0}(\lambda)$ for clear and cloudy skies obtained from Sauberer and Dirmhirn (1958) together with high-resolution values for clear skies from Gast (1960).

\section{DAta Reduction}

The raw optical scans consisted of 230 wavelength steps together with corresponding spectral irradiances. At every probe location several scans were recorded and averaged together to reduce errors due to instrumental noise. Since several fiber-optics probes were 
used concurrently, it was necessary to determine their relative sensitivities. In each experiment sensitivity factors $S_{n}$ were assigned for each probe by substituting data from the no-ice (open-water) measurements into the relationship

$$
S_{n}=F_{\mathrm{o}}(\lambda) /\left\{R_{\downarrow}\left[z_{n}, \lambda\right][\mathrm{I}-\alpha(\lambda)]\right\}
$$

where $R_{\downarrow}\left(z_{n}, \lambda\right)$ was the intensity reading at probe $z_{n}$ (proportional to downwelling irradiance), $F_{0}(\lambda)$ the incident irradiance, and $\alpha(\lambda)$ the albedo. Subsequent readings from each probe were multiplied by the appropriate sensitivity factors to give spectral irradiances.

Sensitivity factors were determined at a wavelength of $490 \mathrm{~nm}$ where absorption by the water column in the tank was negligible. At this wavelength Smith (1973) found an extinction coefficient of $0.0444 \mathrm{~m}^{-1}$ for clear saline water, which when substituted into the BouguerLambert law indicated that the maximum error introduced by absorption in Equation (10) was less than $1.5 \%$.

The two major sources of error in the optical measurements were due to instrumental noise and the large bandpass of the instrument in the infrared. The electronic noise level was independent of wavelength and equal to $\pm 2.5 \mathrm{mV}$ for the most sensitive instrument setting and $\pm 1 \mathrm{mV}$ for lower sensitivities. Consequently, signal-to-noise ratios decreased at shorter wavelengths, and from 400 to $450 \mathrm{~nm}$ they were too low for any meaningful interpretation of the data.

The large bandpass of the instrument at longer wavelengths resulted in errors in the wavelength assigned to a given irradiance. Because the attenuation of ice increases strongly with wavelength, a substantial decrease occurred in the transmitted intensity across the bandpass. As a result the major contribution to the measured irradiance came from the short wavelength side of the band, and the wavelength effectively being measured was significantly shorter than the nominal wavelength at which the instrument was set. This effect was most serious for the transmitted radiation, thus extinction coefficients are not reported for wavelengths greater than $800 \mathrm{~nm}$. Deconvolution techniques were applied in an attempt to increase spectral resolution; however, deconvolution greatly magnified small noise variations and obscured the results beyond $800 \mathrm{~nm}$. Since the reflected radiation did not show such a rapid change with wavelength, albedos were more reliable at longer wavelengths and are reported out to I $000 \mathrm{~nm}$.

\section{Results}

\section{Spectral albedos and extinction coefficients}

Spectral albedos representative of the young salt ice investigated in these experiments are displayed in Figure 2 together with representative curves for snow and thick sea ice. The albedo appears fairly constant from $45^{\circ}$ to $600 \mathrm{~nm}$ and decreases from 600 to $\mathrm{I}$ ooo $\mathrm{nm}$. Curve $\mathrm{I}$ shows the albedo of growing fresh ice for an air temperature of $-15^{\circ} \mathrm{C}$, and curves $2-5$ show albedos of salt ice for air temperatures of $-10,-20,-30$, and $-37^{\circ} \mathrm{C}$. In all cases the ice was approximately $0.2 \mathrm{~m}$ thick. The albedo of fresh ice is less than $25 \%$ of the smallest value for salt ice (curve 2). Comparison of curves $2-5$ indicate that at all wavelengths the albedo is larger for colder, faster-growing ice. This increase is most dramatic (curve 5) when the ice temperature drops below the eutectic point ( $-2 \mathrm{I}{ }^{\circ} \mathrm{C}$ for $\mathrm{NaCl}$ solutions). The presence of solid salts results in an increase in albedo to values comparable to snow. Plotted for comparison are albedos for dry snow (Mellor, 1965), melting first-year blue ice (Grenfell and Maykut, 1977), and melting multiyear white ice (Grenfell and Maykut, 1977). Excluding the case below the eutectic point, the albedos for the much thinner and colder ice examined in these experiments lie between the albedos of melting first-year and multiyear ice. 
Extinction coefficients for the same cases (Fig. 3) exhibit a marked wavelength dependence, increasing slowly between $45^{\circ}$ and $600 \mathrm{~nm}$, then sharply from 600 to $800 \mathrm{~nm}$. Curve 5 , for example, shows a value at $600 \mathrm{~nm}$ which is only $20 \%$ larger than at $500 \mathrm{~nm}$, but by $800 \mathrm{~nm} \kappa_{\lambda}$ is nearly twice as large as the value at $500 \mathrm{~nm}$. As for albedo, the extinction coefficient for ice below the eutectic point is the greatest, with values decreasing for warmer ice. The extinction coefficients measured in these experiments for cold thin ice are, at all wavelengths, considerably larger than previously reported results for thick ice. At $500 \mathrm{~nm}$, for example, $0.24 \mathrm{~m}$

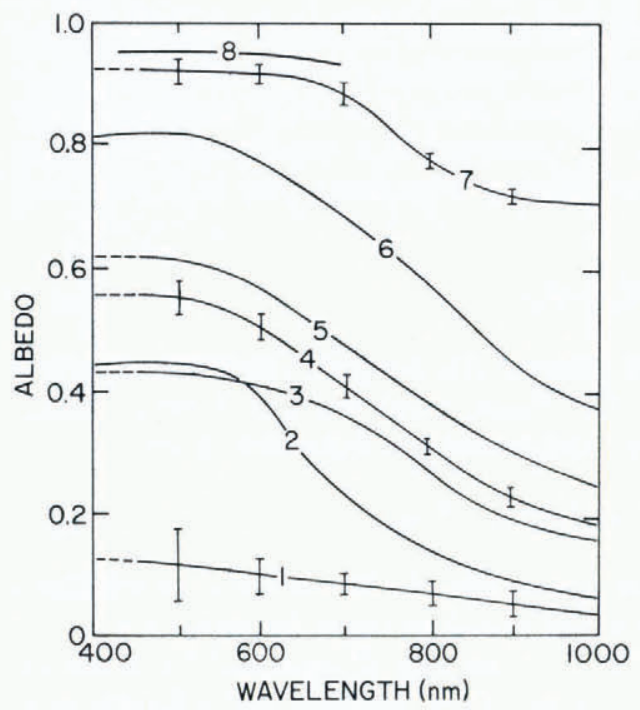

Fig. 2. Spectral albedos of various types of ice: (I) fresh bubbly ice, $H=0.22 \mathrm{~m} ;$ (2) melting first-year blue ice, $\alpha_{\mathrm{BC}}=0.27$ (from Grenfell and Maykut, 1977); (3) full salinity, $H=0.21 \mathrm{~m}, \mathrm{~T}_{\mathrm{air}}=-10^{\circ} \mathrm{C}$, $\alpha_{\mathrm{BC}}=0.37 ;$ (4) full salinity, $H=0.22 \mathrm{~m}$, $T_{\mathrm{air}}=-20^{\circ} \mathrm{C}, \alpha_{\mathrm{BC}}=0.4^{2} ;$ (5) full salinity, $H=0.20 \mathrm{~m}, T_{\mathrm{air}}=-30^{\circ} \mathrm{C}, \alpha_{\mathrm{BC}}=0.53 ;(6)$ melting multiyear white ice (Grenfell and Maykut, 1977), $\alpha_{\mathrm{BC}}=0.69 ;$ (7) full salinity, $H=0.24$, $T_{\mathrm{air}}=-37^{\circ} \mathrm{C}, \alpha_{\mathrm{BC}}=0.86 ;$ and $(8)$ dry snow (Mellor, 1965). The error bars shown for selected curves indicate the uncertainties due to instrumental noise and experimental reproducibility.

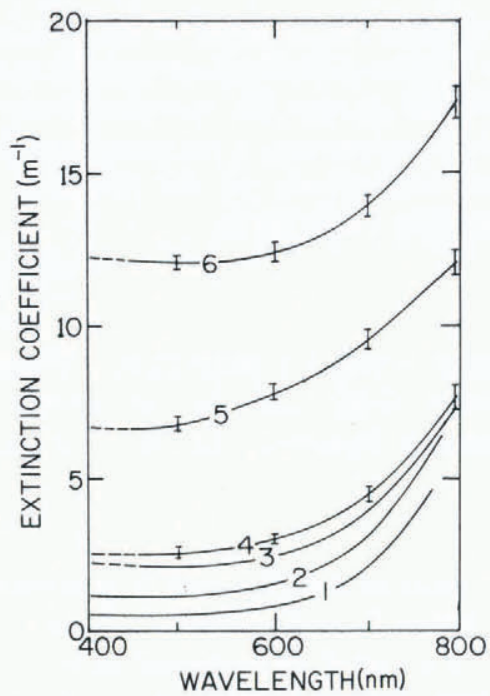

Fig. 3. Spectral extinction coefficients of salt ice and sea ice: (I) ice beneath an old melt pond (Grenfell and Maykut, 1977); (2) interior of melting multiyear white ice (Grenfell and Maykut, 1977); (3) full salinity, $H=0.21 m, T_{\text {air }}=-10^{\circ} \mathrm{C}, \alpha_{\mathrm{BC}}=0.37 ;$ (4) full salinity, $H=0.22 \mathrm{~m}, \quad T_{\mathrm{air}}=-20^{\circ} \mathrm{C}$, $\alpha_{\mathrm{BC}}=0.4^{2} ;$ (5) full salinity, $H=0.20 \mathrm{~m}$, $T_{\mathrm{air}}=-30^{\circ} \mathrm{C}, \alpha_{\mathrm{BC}}=0.53 ;$ and $(6)$ full salinity, $H=0.24 m, T_{\text {air }}=-37^{\circ} \mathrm{C}, \alpha_{\mathrm{BC}}=0.86$. The error bars shown for selected curves indicate the uncertainties due to instrumental noise and experimental reproducibility.

thick ice at an air temperature of $-30^{\circ} \mathrm{C}$ has an extinction coefficient which is twice that measured in the surface granular layer of multiyear white ice and ten times greater than values for the interior of multiyear white ice (Grenfell and Maykut, 1977). The bulk extinction coefficient for this case, calculated from

$$
\kappa=\int_{400}^{800} \kappa_{\lambda} F_{\text {net }}(z, \lambda) \mathrm{d} \lambda / \int_{400}^{800} F_{\text {net }}(z, \lambda) \mathrm{d} \lambda
$$

where $F_{\text {net }}(z, \lambda)=F_{\downarrow}(z, \lambda)-F_{\uparrow}(z, \lambda)$, is $7.4 \mathrm{~m}^{-1}$ at $0.10 \mathrm{~m}$ under cloudy conditions. This is approximately $5 \frac{1}{2}$ times larger than the values of 1.5 and $1.2 \mathrm{~m}^{-1}$ measured by Untersteiner (I96I) and Weller and Schwertfeger (1967) for multiyear ice and first-year ice respectively. 
In order to provide an independent check of the above results, a method of determining the bulk extinction coefficient from the heat absorbed in the ice was used (Untersteiner, I96I). In general, the heat balance of the ice can be expressed (Carslaw and Jaeger, I959) by

$$
k \frac{\partial^{2} T}{\partial z^{2}}+\frac{\partial F_{\text {net }}(z)}{\partial z}=\rho C_{S} \frac{\partial T}{\partial t}
$$

where $k$ is the thermal conductivity, $\partial F_{\text {net }}(z) / \partial z$ is the radiative heating, $\rho$ is the ice density, and

$$
C_{S}=2.09+\mathrm{I} .72 S / T^{2}\left(\mathrm{~J} \mathrm{~g}^{-1} \mathrm{deg}^{-1}\right) .
$$

The relative importance of the conductive and radiative terms in Equation (12) was tested using a finite-difference scheme. For typical experimental conditions it was found that below a depth of $40 \mathrm{~mm}$ the conduction term could be neglected when the "sun" was on. Under these circumstances, a temperature rise from $T_{0}$ to $T_{1}$ occurring in a time interval $t$ can be related analytically to the radiative heating by combining Equations (12) and (13) and integrating. This gives

$$
\frac{\partial F_{\text {net }}(z)}{\partial z} t=\rho A\left(T_{1}-T_{0}\right)
$$

where $A=2.09+\mathrm{r} .72 S /\left(T_{0} T_{\mathrm{I}}\right)$. Over a small depth interval $\Delta z$, the depth dependence of the radiation field, can be accurately represented by $F_{\text {net }}(z+\Delta z)=F_{\text {net }}(z) \exp (-\kappa \Delta z)$. Evaluating Equation (14) at $z+\Delta z$ and $z$, dividing, and taking the logarithm gives

$$
\kappa=-\frac{\mathrm{I}}{\Delta z} \ln \left\{\left[A\left(T_{\mathrm{I}}-T_{\mathrm{o}}\right)\right]_{z_{+\Delta} z} /\left[A\left(T_{\mathrm{I}}-T_{\mathrm{o}}\right)\right]_{z}\right\} .
$$

Since most of the infrared is absorbed in the upper $40-50 \mathrm{~mm}$, bulk extinction coefficients determined from Equation (I 5 ) are directly comparable to values from Equation (I I).

This method was applied to ice grown at $-30^{\circ} \mathrm{C}$. The ice was illuminated for $200 \mathrm{~min}$, with temperature profiles recorded at the beginning and end of that period. The resulting heat absorption profile, $A\left(T_{1}-T_{0}\right)$ versus $z$, is shown in Figure 4 . Below $40 \mathrm{~mm}$ the curve is

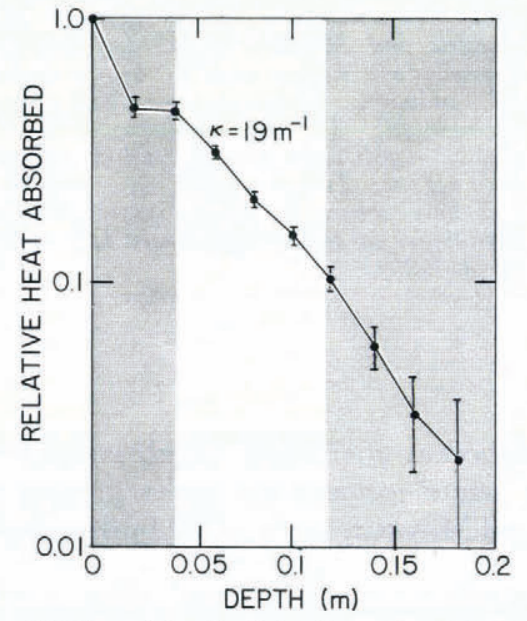

Fig. 4. Depth profile of relative heat absorbed during a 200 min period of illumination for salt ice grown at $T_{\text {air }}=-30^{\circ} \mathrm{C}$. The bulk extinction coefficient is determined from section of the profile in the unshaded region. The error bars show the variations in heat absorbed resulting from the uncertainty in the temperature and salinity measurements.

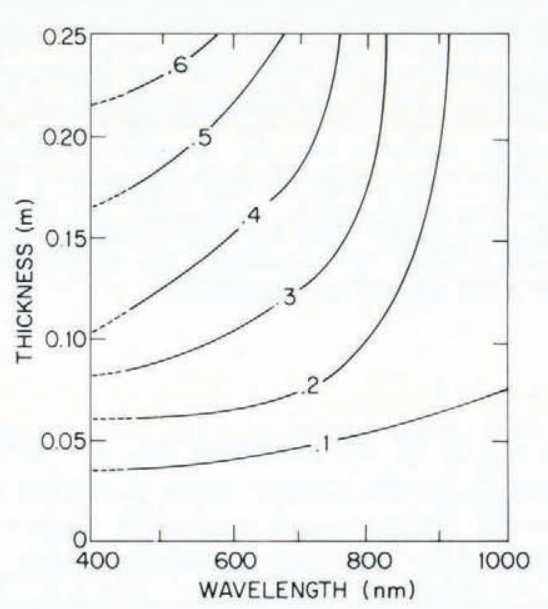

Fig. 5. Isopleths of albedo as a function of wavelength and thickness for salt ice grown at $T_{\text {air }}=-20^{\circ} \mathrm{C}$. 
logarithmic and the resultant extinction coefficient from Equation ( 15 ) is $19 \mathrm{~m}^{-\mathrm{I}}$. Using the spectrum of a $4800 \mathrm{~K}$ black body, Equation (I I ) gives an extinction coefficient of $18 \mathrm{~m}^{-1}$ at a depth of $60 \mathrm{~mm}$. The results of two methods agree to within $5 \%$ confirming that $\kappa$ is considerably larger for young growing ice than for thick first-year or multiyear sea ice.

\section{The dependence of the optical properties on physical parameters}

Sea ice is a complex medium whose structure depends on its thickness, temperature, salinity, and brine volume. Initially, however, the structure is determined by the growth conditions and is influenced by the subsequent thermal history. While it was impractical to define the complete dependence of the optical properties on all the above-mentioned parameters, it was possible using the set of cases described in the laboratory experiments section to achieve an understanding of the basic dependences and their relative importance.

For increasing ice thickness the albedo increased and the transmission decreased. Figure 5 displays isopleths of albedo as a function of wavelength and thickness for salt ice grown at an air temperature of $-20^{\circ} \mathrm{C}$. At short wavelengths the increase of albedo with thickness was greatest and continued throughout the entire growth phase (up to $0.25 \mathrm{~m}$ ). At wavelengths greater than about $700 \mathrm{~nm}$ the albedo reached a maximum value part way through the experiment which it held as the ice continued growing. The ice thickness where the maximum was reached decreased for longer wavelengths. In all other experiments the same qualitative behavior was observed.

This behavior is due primarily to the addition of scattering layers as the ice grows coupled with an increased path length which backscattered light must traverse to emerge at the surface; therefore, the albedo increases rapidly at first and then more gradually until the contribution from additional layers is negligible. Since absorption by the ice increases with wavelength, the thickness of ice contributing to the albedo decreases with increasing wavelength.

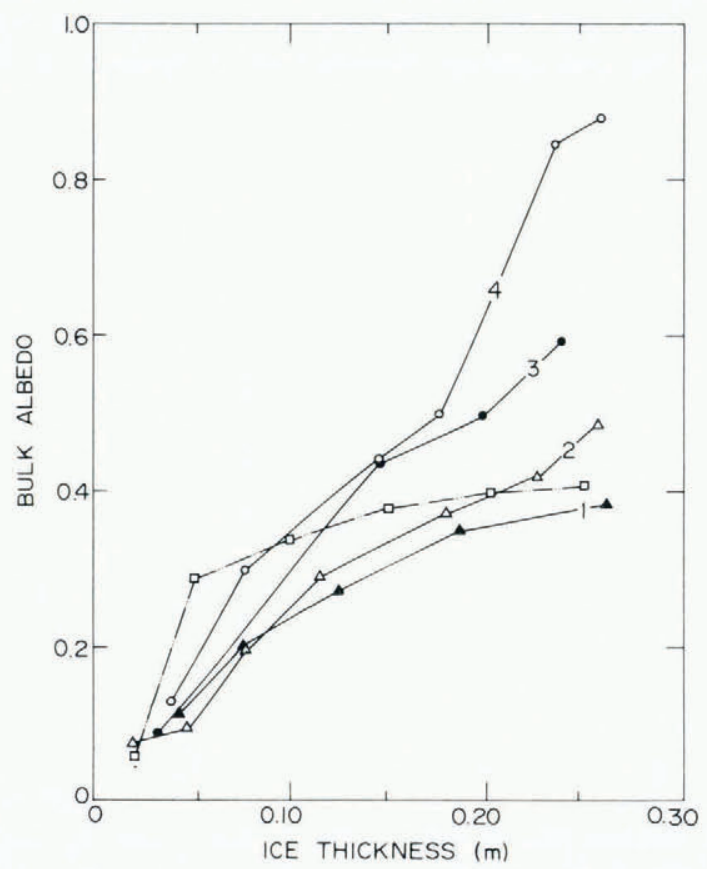

Fig. 6. Bulk albedo for cloudy skies as a function of ice thickness for salt ice for $(I) T_{\mathrm{air}}=-10^{\circ} \mathrm{C} ;(2) T_{\mathrm{air}}=-20^{\circ} \mathrm{C}$; (3) $T_{\text {air }}=-30^{\circ} \mathrm{C}$; and (4) $T_{\text {air }}=-37^{\circ} \mathrm{C}$. The broken curve represents the results obtained by Weller (1972) using a Kipp radiometer. 
Bulk albedos show a similar behavior. The thickness dependence of bulk albedo for the full salinity experiments is shown in Figure 6. The curves exhibit a rapid initial increase followed by a more gradual rise as the thickness continues to grow. Comparing the curves for - Io and $-20^{\circ} \mathrm{C}$ with the results of Grenfell (1979) for blue ice indicates that four to five times the thickness of blue ice would be necessary to produce the same bulk albedos. The large increase of curve 4 occurs when the temperature in the upper few centimeters drops below the eutectic point. Also included are the results of Weller (1972) using a Kipp radiometer. During the first $0.05 \mathrm{~m}$ of growth, his curve increases more rapidly than curves $\mathrm{I}$ to 4 , but its subsequent increase is more gradual so that it crosses through the range defined by curves 2 to 4 and approaches curve I. The larger initial rise of Weller's results may have been caused by frost flower formation or other variations in the environment which did not occur during the laboratory studies. The more gradual rise for ice thicker than $0.05 \mathrm{~m}$ may be due to the contributions to $F_{0}(\lambda)$ and $\alpha_{\lambda}$ from the I ooo to $3000 \mathrm{~nm}$ wavelength region which is detected by the Kipp radiometer but falls outside the range of the spectrophotometer.

The albedo was also sensitive to ice surface conditions. When the surface became crumbly and irregular due to brine drainage (at the start of the melt phase for example) the enhanced backscattering resulted in larger albedos. Conversely, formation of a brine skim filled in surface irregularities reducing backscattering and decreasing the albedo. Since these effects resulted from temperature changes, their magnitudes could not be accurately determined.

An additional effect is due to a decrease in the temperature of the upper layers as the ice grows. For example, in the $-37^{\circ} \mathrm{C}$ experiment the surface temperature dropped below the eutectic point at an ice thickness of about $0.2 \mathrm{~m}$ and the albedo increased sharply.

The influence of temperature could be studied most conveniently during the warming phase of an experiment when changes in ice thickness, crystal structure, and salinity were small. To show the largest variation, spectral albedos and extinction coefficients from the $-37^{\circ} \mathrm{C}$ experiment are displayed in Figures 7 and 8 . After each set of optical measurements the air temperature was raised and the ice allowed to reach thermal equilibrium before the next set was taken. A strong temperature dependence is evident; a dramatic decrease in

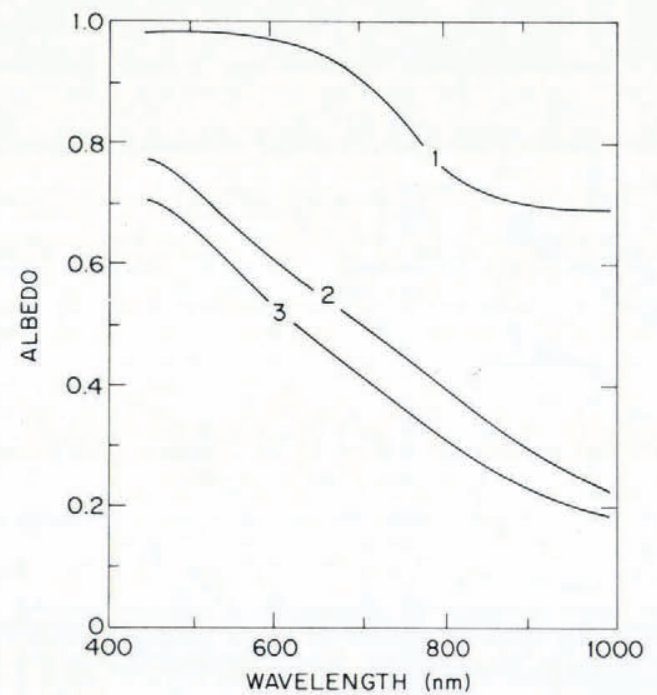

Fig. 7. Spectral albedos from the warming phase of the $-37^{\circ} \mathrm{C}$ full salinity experiment for $H=0.27 \mathrm{~m}$ : (I) $T_{\text {air }}=-37^{\circ} \mathrm{C}, \quad \alpha_{\mathrm{BC}}=0.9^{\circ} ;$ (2) $T_{\mathrm{air}}=$ $-22^{\circ} \mathrm{C}, \quad \alpha_{\mathrm{BC}}=0.59 ;$ and (3) $T_{\mathrm{air}}=-2^{\circ} \mathrm{C}$, $\alpha_{\mathrm{BC}}=0.5 I$.

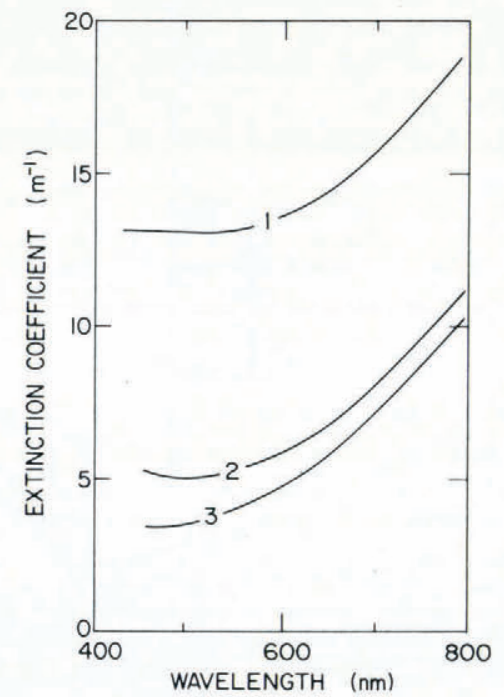

Fig. 8. Spectral extinction coefficients from the warming phase of the $-37^{\circ} \mathrm{C}$ full-salinity experiment. The curves correspond to the same cases as described in Figure 7. 
albedo and extinction coefficient occurs as the ice temperature rises above the eutectic point and the salt crystals go into solution. Subsequent changes are less extreme, but both $\alpha_{\lambda}$ and $\kappa_{\lambda}$ continue to decrease with increasing temperature, due to the increase in brine volume which reduces backscattering in the ice.

The dependence on brine volume $V_{\mathrm{B}}$ can be expressed explicitly using $V_{\mathrm{B}}=-0.055 S / T$. Bulk albedos versus average brine volume for the warming phases of three full-salinity experiments are shown in Figure 9. Results from each individual experiment show a decrease in albedo with increasing brine volume. In each case, however, the growth conditions, and hence the distribution of brine within the ice, are quite different. The family of curves in Figure 9 indicates that not only does albedo depend on brine volume but also, for a given brine volume, faster grown ice has a larger albedo.

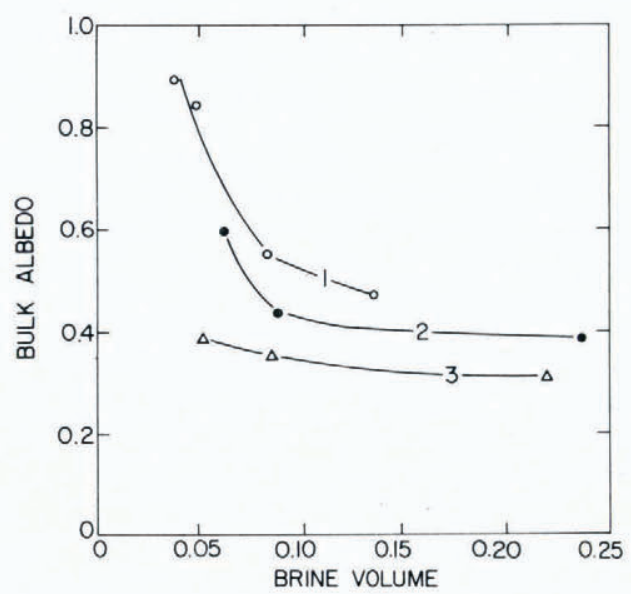

Fig. 9. Bulk albedo for cloudy skies versus brine volume from measurements taken during the warming phase of thrze full-salinity experiments. The air temperatures during freezing were $(\mathrm{I})-37^{\circ} \mathrm{C} ;(2)-30^{\circ} \mathrm{C}$; and $(3)-10^{\circ} \mathrm{C}$.

To isolate the effect of the growth rate on the optical properties, cases were compared where the growth conditions were different (air temperatures of $-10,-30,-37^{\circ} \mathrm{C}$ ), but the ice thickness and temperature profiles were nearly the same. During the warming phase in each of the three cases the air temperature was raised to $-2{ }^{\circ} \mathrm{C}$ and the ice was allowed to come to thermal equilibrium. The optical properties measured at this point show a distinct correlation with growth rate (Figs ro and I I). Even when brought to the same temperature, the faster-grown ice exhibits albedos and extinction coefficients which are $67 \%$ and $300 \%$ larger, respectively, than for the slowest-grown ice.

Changes in growth rate affect the optical properties by altering the number of brine-ice interfaces. As the growth rate increases, more brine is entrapped and the platelet and crystal sizes decrease (Weeks and Hamilton, 1962; Weeks and Assur, 1967). Weeks and Assur (1967) empirically related platelet spacing and growth rate by

$$
a=\left(p / \frac{\mathrm{d} H}{\mathrm{~d} t}\right)^{\frac{1}{t}}
$$

where $a$ is the platelet spacing, $\mathrm{d} H / \mathrm{d} t$ is the growth rate, and $p$ is $1.33 \times 10^{-4} \mathrm{~mm}^{3} / \mathrm{s}$. Predicted platelet spacings at a depth of $0.1 \mathrm{~m}$ range from $0.28 \mathrm{~mm}$ to $0.54 \mathrm{~mm}$ for the full-salinity experiments. Crystal sizes and platelet spacings in the tank experiments were checked periodically and found to follow these trends. Smaller platelets and crystals imply more scattering inhomogeneities per unit volume. 


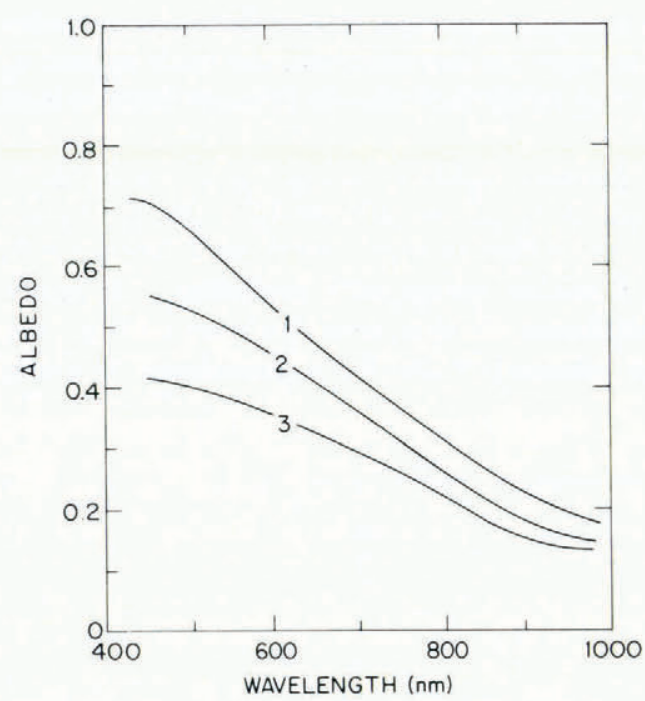

Fig. Io. Spectral albedos for ice with similar temperature profiles, but grown at different air temperatures. In each case the ice was about $0.28 \mathrm{~m}$ thick, the air temperature was approximately $-2^{\circ} \mathrm{C}$, and the ice was grown at air temperatures of $(\mathrm{I})-37^{\circ} \mathrm{C}$; (2) $-30^{\circ} \mathrm{C}$; and (3) $-10^{\circ} \mathrm{C}$. Corresponding values of $\alpha_{\mathrm{BC}}$ were $0.5 \mathrm{I}$, 0.42 , and 0.33 , respectively.

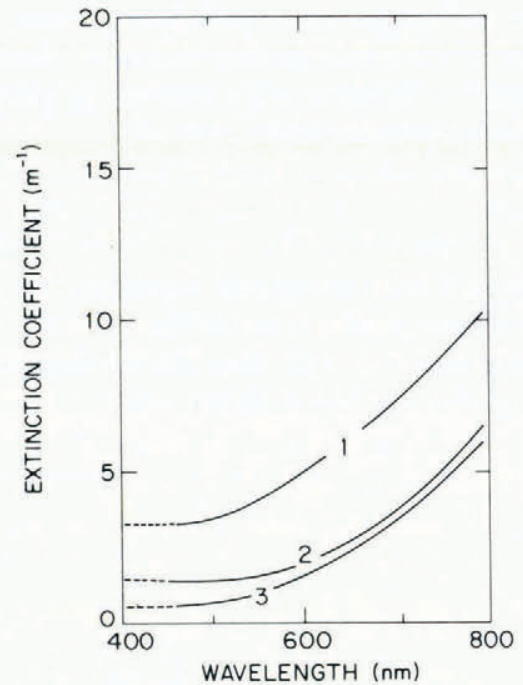

Fig. II. Spectral extinction coefficients for ice with similar temperature profiles, but grown at different air temperatures. The curves correspond to the same cases as described in Figure 10.

To investigate the role of salinity, two intermediate-salinity experiments were performed. Environmental conditions during these experiments were identical to two of the full-salinity cases, except that the water salinity was $16 \%$. At the lower water salinity, about half as much brine was entrapped despite similar growth conditions. By duplicating the air temperature of previous experiments, ice temperature profiles and growth rates were the same to within $10 \%$. No significant differences were found in the spectral albedos and extinction coefficients between corresponding full- and partial-salinity experiments. This is in agreement with Lane's (1975) results which suggested that above $4 \%$ ice salinity appears to have little effect on light transmission. As salinity decreases below $4 \%$ the albedo and extinction coefficients decrease to their limiting values for fresh ice; however, for the relatively high salinities investigated here, the optical properties do not depend on salinity to within the resolution of the experiments.

If it is true that the optical properties are insensitive to ice salinity, we would also expect the platelet spacing to be insensitive to water salinity during the growth phase. To test this possibility, calculated values of platelet spacing were compared with observations at depths of $0.10,0.15$, and $0.20 \mathrm{~m}$ for the -10 and $-20^{\circ} \mathrm{C}$ intermediate-salinity cases. The calculated values agreed with measured values in five out of six cases, which suggests that Equation (I6) also describes ice grown from $16 \%$ salinity water and that, between $16 \%$ and $32 \%$, platelet spacing is at most weakly dependent on the water salinity. While a much more thorough analysis is required to confirm this result, it is consistent with our hypothesis.

\section{Small-scale ice structure}

To study the behavior of the brine and crystal structure with changes in temperature, a core was removed during the $-30^{\circ} \mathrm{C}$ full-salinity experiment and a sample was prepared for observation under a Wild microscope fitted with a camera attachment. The sample was a 


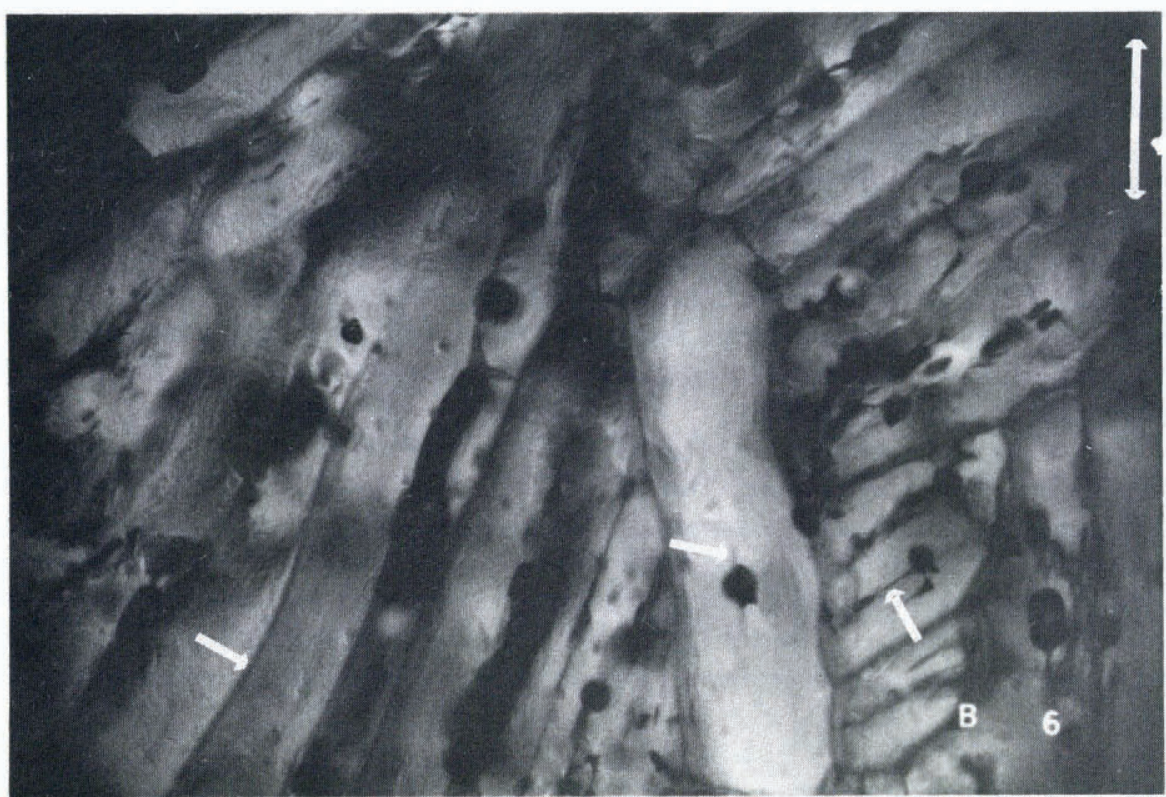

(a)

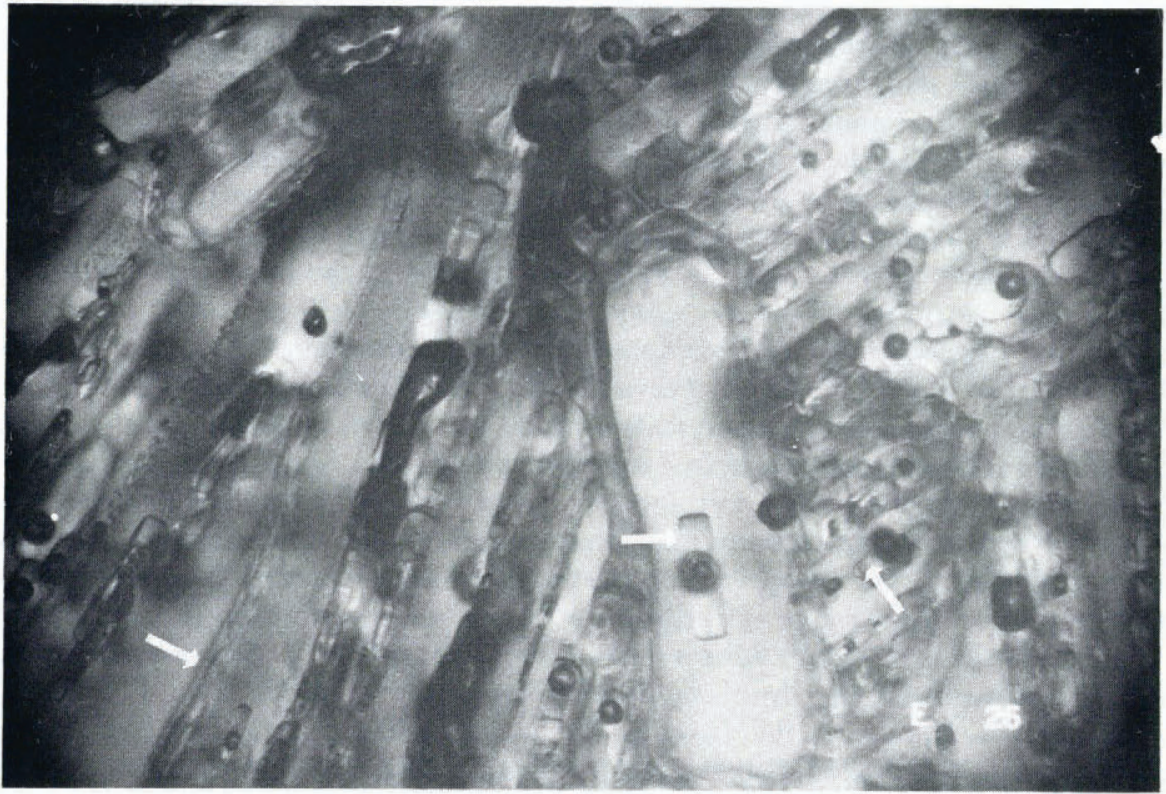

(b)

Fig. 12. Photomicrographs of a horizontal thin section. The double-headed arrow in photograph $(a)$ is $1 \mathrm{~mm}$ in length. (a) $T_{\text {ice }}=-27^{\circ} \mathrm{C} ;\left(\right.$ b) $T_{\text {ice }}=-I^{\circ} \mathrm{C}$. 
horizontal section, roughly $7 \mathrm{~mm}$ thick from o. $\mathrm{m} \mathrm{m}$ deep in the ice, with a salinity of I I. $2 \%$. At this depth the crystals were orderly and oriented with horizontal $c$-axes, and were typically Io $\mathrm{mm}$ across. The sample was frozen onto a glass plate, further thinned using a bandsaw, and then polished. To minimize brine drainage from the sample the preparation was performed at a temperature of $-25^{\circ} \mathrm{C}$. Finally, water was frozen around the periphery of the sample to seal the edges, inhibiting subsequent brine drainage. The sample was then placed under the microscope and warmed over a period of two days. During this time a series of photomicrographs was taken at 14 temperatures between -27 and $-\mathrm{I}^{\circ} \mathrm{C}$. The first and last photographs are presented in Figure 12. The arrows point out representative features at the beginning and end of the warming sequence. The thin dark lines between platelets in Figure 12a are due to the precipitated salts. These lines do not appear in Figure 12b taken above the eutectic point.

The photomicrographs illustrate several points regarding changes in ice structure during warming. Below the eutectic point the ice appears very white due to the presence of solid salts at the platelet boundaries. Above the eutectic point the salt goes into solution, and the structure variations with temperature are less obvious. As the temperature is raised, the brine volume increases and the platelet boundaries become broader arid smoother. Small isolated pockets of brine enlarge and often interconnect. Similarly, small air bubbles released within the ice by melting can join together. These changes reduce light scattering within the ice.

\section{Conclusions}

The optical properties of young growing sea ice are markedly different from those of melting first-year and multiyear ice. Extinction coefficients are as much as 15 times greater; and in order for a layer of summer sea ice to have the same albedo, its thickness would have to be four to five times as large.

Since the absorption coefficients of brine and pure ice are essentially independent of temperature, the optical properties of sea ice are governed by the effectiveness of scattering in the ice. Enhanced scattering results in higher albedos; it also increases the extinction coefficient because the optical path length is greatly increased by multiple scattering with a corresponding increase in the probability that the light will be absorbed in the ice. Scattering in turn is determined primarily by the platelet structure and the distribution of brine between the platelets. The amount of scattering is inversely related to the temperature. As brine pockets and channels open up with increasing temperature the brine-ice interfaces coalesce and become more rounded. If the ice temperature drops below the eutectic point, salt crystals are precipitated out causing a sudden increase in the scattering. Growth rate is important because it determines the platelet and crystal sizes and the initial distribution of brine in the ice. Albedo is also influenced by changes in surface conditions. Flooding of the surface due to melting or to concentrated brine being squeezed out gives a smooth surface and lowers the albedo, and melting followed by drainage leaves a crumbly surface with a higher albedo.

From these results it can be concluded that in general the extinction coefficient will vary with depth and time since the optical properties respond to changes in the temperature and brine distribution. A wide range of variation is apparent in the data from the limits mentioned at the beginning of this section to values measured at the end of the melt phase which are much closer to those of summer ice; thus, the optical properties of sea ice should be in a continual state of change. In the Arctic this involves a transient phase for the first two years until the salinity profile stabilizes followed by a cyclic variation with seasonal environmental changes.

A number of problems remain. While the results of the present experiments isolate the effects which influence the optical properties, further work is necessary to give a quantitative connection between $\alpha$ and $\kappa$ and the ice structure. The weak dependence of the optical properties on water salinity should be examined in more detail. Finally, the effects of vapor 
bubbles have not been studied here, but must be included in any general theory of the optical properties of sea ice. A study of each of these problems would require laboratory measurements of light scattering by small ice samples in combination with a comprehensive radiative transfer model. Incorporating the present results into a regional albedo model for polar sea ice would require including the influence of a snow layer which usually accumulates on newly formed ice and sharply increases the albedo.

\section{Acknowledgements}

We would like to thank Ms Kathy Jones for her able assistance in the laboratory experiments, Dr Gary Maykut for his many helpful suggestions in preparing the text, and Mr Peter Kauffman for his help in improving and maintaining the electronics. This work was made possible by continued support from the Office of Naval Research, Arctic Program, under Contract Nooor4-76-C-0234.

MS. received I $_{3}$ December 1979

\section{REFERENCES}

Burt, W. V. 1954. Albedo over wind roughened water. Fournal of Meteorology, Vol. I I, No. 4, p. 283-90.

Carslaw, H. S., and Jaeger, J. C. 1959. Conduction of heat in solids. Second edition. Oxford, Clarendon Press.

Chernigovskiy, N. T. 1963. Radiatsionnyye svoystva ledyanogo pokrova tsentral'noy Arktiki [Radiational properties of the central Arctic ice cover]. Trudy Arkticheskogo $i$ Antarkticheskogo Nauchno-Issladovatel'skogo Instituta, Tom 253, p. 249-6o.

Davis, H. T., and Munis, R. H. 1973. Effect of salinity on the optical extinction of sea ice at $6328 \AA$. U.S. Cold Regions Research and Engineering Laboratory. Research Report 308.

Dunkle, R. V., and Bevans, J. T. I956. An approximate analysis of the solar reflectance and transmittance of a snow cover. Fournal of Meteorology, Vol. 13 , No. 2, p. 212-16.

Gast, P. R. I960. Solar radiation. (In Campen, C. F., and others, ed. Handbook of geophysics. Edited by C. F. Campen [and 5 others]. New York, Macmillan, p. 16-14-16-32.)

Grenfell, T. C. 1979. The effects of ice thickness on the exchange of solar radiation over the polar oceans. Fournal of Glaciology, Vol. 22, No. 87, p. 305-20.

Grenfell, T. C., and Maykut, G. A. 1977. The optical properties of ice and snow in the Arctic basin. Journal of Glaciology, Vol. 18, No. 8o, p. $445^{-63}$. Hanson, K. J. 196r. The albedo of sea ice and ice islands in the Arctic Ocean basin. Arctic, Vol. 14, No. 3,
p. 188-96.

Lane, J. W. 1975. Optical properties of salt ice. Journal of Glaciology, Vol. 15, No. 73, p. 363-72.

Langleben, M. P. 1968. Albedo measurements of an Arctic ice cover from high towers. Fournal of Glaciology, Vol. 7 , No. 50, p. $289-97$.

Langleben, M. P. 1971. Albedo of melting sea ice in the southern Beaufort Sea. Fournal of Glaciology, Vol. ro, No. 58 , p. $10 \mathrm{I}-04$

Maykut, G. A. 1978. Energy exchange over young sea ice in the central Arctic. Journal of Geophysical Research, Vol. 83 , No. C7, p. 3646-58.

Maykut, G. A., and Grenfell, T. C. 1975. The spectral distribution of light beneath first-year sea ice in the Arctic Ocean. Limnology and Oceanography, Vol. 20, No. 4, p. 554-63.

Mellor, M. 1965. Optical measurements on snow. U.S. Cold Regions Research and Engineering Laboratory. Research Report $\mathrm{i} 69$.

Perovich, D. K. 1979. The optical properties of young sea ice. Seattle, Dept. of Atmospheric Sciences, University of Washington. (U.S. Office of Naval Research. Contract Nooor 4-76-C-O234. Project No. 307-252. Scientific
Report No. 1 7.)

Roulet, R. R., and others. 1974. Spectrophotometers for the measurement of light in polar ice and snow, by R. R. Roulet, G. A. Maykut, and T. C. Grenfell. Applied Optics, Vol. 13, No. 7, p. 1652-58.

Sauberer, F., and Dirmhirn, I. 1958. Das Strahlungsklima. (In Steinhauser, F., and others, ed. Klimatographie von Österreich. Hrsg. und bearbeitet von F. Steinhauser, O. Eckel, F. Lauscher. Ósterreichische Akademie der Wissenschaften. Denkschriften der Gesamtakademie, Bd. 3, 1. Lief., p. 13-102.)

Smith, R. C. r 973 . Optical properties of the Arctic upper water. Arctic, Vol. 26, No. 4, p. 303-13. Thomas, C. W. 1963 . On the transfer of visible radiation through sea ice and snow. Fournal of Glaciology, Vol. 4 ,
No. 34, p. $48 \mathrm{r}-84$.

Timerev, A. A. I970. Yestestvennaya osveshchennost' i proniknoveniye sveta v sneg v tsentral'noy Arktike [Natural illuminance and penetration of light into snow in the central Arctic]. Problemy Arktiki i Antarktiki, Vyp. 34, p. 35-41. 
Untersteiner, N. 1961. On the mass and heat budget of Arctic sea ice. Archiv für Meteorologie, Geophysik und Bioklimatologie, Ser. A, Bd. 12, Ht. 2, p. 151-82.

Weeks, W. F., and Assur, A. I967. The mechanical properties of sea ice. U.S. Cold Regions Research and Engineering Laboratory. Cold regions science and engineering. Hanover, N.H., Pt. II, Sect. C3.

Weeks, W. F., and Hamilton, W. L. 1962. Petrographic characteristics of young sea ice, Point Barrow, Alaska. American Mineralogist, Vol. 47, Nos. 7-8, p. 945-6r.

Weller, G. E. 1972. Radiation flux investigations. AIDJEX Bulletin, No. 14, p. 28-30.

Weller, G. E., and Schwerdtfeger, P. 1967. Radiation penetration in Antarctic plateau and sea ice. (In Polar meteorology. World Meteorological Organization Technical Note No. 87, p. 120-41. (WMO-No. 21 I. TP. 1 I 1 .)) 